\title{
Does governance matter? Country-level determinants of operational risk
}

\author{
EDINA BERLINGER ${ }^{1}$, JUDIT LILLA KERESZTÚRI ${ }^{1 *}{ }^{*}$, \\ ÁGNES LUBLÓY ${ }^{2}$ and ZSUZSANNA TAMÁSNÉ VŐNEKI ${ }^{3}$
}

\footnotetext{
${ }^{1}$ Department of Finance, Corvinus University of Budapest, Budapest, Hungary

${ }^{2}$ Department of Accounting and Finance, Stockholm School of Economics in Riga, Rìga, Latvia

${ }^{3}$ Operational Risk Management Department, OTP Bank, Budapest, Hungary
}

Received: April 1, 2021 - Revised manuscript received: August 13, 2021 - Accepted: September 2, 2021

Published online: October 8, 2021

(C) 2021 The Author(s)

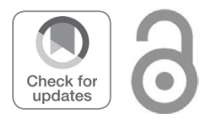

\begin{abstract}
The severity and frequency of operational loss events show high variability across the globe. In this paper, we first examine the extent to which the quality of country-level governance measured by the Worldwide Governance Indicators explains cross-country variation of operational losses. We use the comprehensive database of SAS OpRisk Global for the period of 2008-2019 covering 132 countries and 8,144 loss events with a total loss amount of almost 490 billion USD. Our findings indicate that the governance indicators lost their explanatory power over the past decades, which contradicts the academic consensus and calls for new explanatory variables. To find these variables, we hypothesize that the changes are driven by some important megatrends such as economic development and technological advancement, globalization, and sustainability. Accordingly, we propose an extended model where the number of mobile subscribers, the export to GDP ratio, and the poverty headcount ratio were significant for the frequency. For severity, only GDP is a significant and robust explanatory variable. Investors, regulators, and analysts should, therefore, concentrate on these factors if they wish to model, manage, or mitigate operational risks.
\end{abstract}

\section{KEYWORDS}

operational losses, severity, frequency, governance

\section{JEL CLASSIFICATION CODES}

G32, G38, D83

*Corresponding author. E-mail: lilla.kereszturi@uni-corvinus.hu 


\section{INTRODUCTION}

Operational risk is defined as "the risk of loss resulting from inadequate or failed internal processes, people, and systems, or from external events" (BCBS 2004: 14). It is the second most important source of risk for financial institutions measured by the size of the capital requirement set by the regulator (ECB 2017). Non-financial institutions face significant operational risks as well; for them business process management is of top priority. Rapid technological development, the accelerating complexity of the global market, and the substantial environmental risks underline the increasing threat posed by operational risks (Allen - Saunders 2004).

The largest operational losses are related to environmental disasters, compensation of unsatisfied stakeholders, and frauds which have serious consequences on business continuity, financial performance, and long-term sustainability. According to the previous literature, operational risk depends on the quality of firm- and country-level governance (Chernobai et al. 2011; Cope et al. 2012). Better-governed firms operating in better-governed countries are less risky, and thus are more attractive to investors, which can be reflected in a lower cost of capital.

Operational risks, both the severity (average size) and frequency (average number) of loss events, vary greatly across countries. In the SAS OpRisk Global database, countries with the highest severity include the United States, the United Kingdom, Japan, Germany, China, Japan, Brazil, India, the Ukraine, Russia and Argentina. At the lower end, we find countries such as Slovakia, Luxembourg, Cuba, Yemen, Morocco, Moldova. Countries with the highest frequency overlap with countries with the highest average loss amount only partly; the top 10 countries by frequency are the United States, India, the United Kingdom, Australia, Russia, Italy, China, Canada, France, and Brazil.

Empirical literature on country-level operational losses suggests that economies - just like firms - can operate under two regimes resulting in either "high frequency and low severity" (HFLS) or "low frequency and high severity" (LFHS) losses. In general, the type of the regime depends on the quality of the country-level governance (Cope et al. 2012; Li - Moosa 2015; Curti - Mihov 2018; Alifano et al. 2019). Thus, the academic consensus is that in better-governed countries, we can expect more but smaller operational losses as procedures are continuously monitored and improved. In contrast, in countries with poor governance, feedback mechanisms are weaker; hence, we can expect rare but severe (Chernobil-type) losses.

The aim of this study is to challenge the academic consensus and investigate the impact of the quality of governance on the severity and frequency of large operational loss events $(>\$ 100,000)$. We use a comprehensive and recent database, the SAS OpRisk Global 2008-2019, covering 132 countries and 8,144 loss events with a total loss amount of almost 490 billion USD. First, we measure the quality of governance by the Worldwide Governance Indicator similar to Li and Moosa (2015) and Curti and Mihov (2018). Second, the components of the indicator are entered into the regressions one by one similar to Cope et al. (2012) and Alifano et al. (2019). The six components of the indicator include 1) voice and accountability; 2) political stability and absence of violence; 3) government effectiveness; 4) regulatory quality; 5) rule of law; and 6) control of corruption; for more details, see Kaufmann et al. (2011).

As a first step, we replicate the study of Li and Moosa (2015) on a larger and more recent data sample. In different specifications, we use not only the severity and frequency of losses as dependent variables but also the total loss amount and the maximum loss amount. In addition to the main explanatory variable of interest (governance indicators), we introduce the same 
control variables as Li and Moosa (2015): the size of the economy (GDP), living standards (GNI per capita), the legal system, and the geographical region. We run several robustness checks, for example 132 (our sample) versus 53 countries (sample of Li and Moosa (2015)); all industries versus subsamples of the finance and non-finance sectors; full period of 2008-2019 versus subsamples for 2008-2013 (post crisis) and 2014-2019 (boom); aggregate governance index versus its components one-by one.

We find that only two governance indicators (government effectiveness and control of corruption) are significant for severity (53 countries, all industries), but contrary to the expectations, with positive signs. Moreover, the aggregate governance indicator is insignificant in all but one specification. Thus, practically, governance indicators lost their explanatory power since the study of Li and Moosa (2015) covering the period of 1975-2008.

Consequently, factors explaining operational losses must have fundamentally changed in the past decades. These changes might be driven by megatrends i.e., large social, economic, political, technological, or environmental changes that are relatively slow to form but influence all human activities deeply (Naffa - Fain 2020). Related to operational losses, we identify three important megatrends: (i) economic development and technological advancement; (ii) globalization; and (iii) sustainability. To identify factors which may potentially explain operational losses, we extend the model of $\mathrm{Li}$ and Moosa (2015) with nine new proxy variables, three for each important megatrend.

Although the governance indicators remain insignificant in the extended model, we identify some additional significant variables (for severity, or frequency, or total loss), one for each megatrend: the number of mobile subscriptions (corresponding to the megatrend of economic development and technological advancement), export to GDP ratio (corresponding to the megatrend of globalization), and the poverty headcount ratio (corresponding to the megatrend of sustainability). Some variables (GDP and regions) adopted from the model of Li and Moosa (2015) are still significant, which highlights that the size of the economy and regional (thus, cultural and historical) factors have retained their importance over time.

The novelty of our research lies in demonstrating that country-level governance has lost its explanatory power for operational losses when using a comprehensive and more recent database. At the same time, we propose some new variables that can be helpful in modelling operational risk. Although our findings contradict the empirical literature, they are robust across different specifications.

In Section 2, we review the literature in more detail. In Section 3, we present the data and the methods. In Section 4, we summarize the regression results for both the original model of Li and Moosa (2015) and the proposed extended model. Finally, we discuss results in Section 5, and draw the conclusions and summarize the policy implications in Section 6.

\section{LITERATURE REVIEW}

Chernobai et al. (2011) analyzed firm-level control mechanisms and incentive systems and found that a higher level of antitakeover provisions, more stock options, and a higher bonus/salary ratio for the $\mathrm{CEO}$ were associated with higher operational risk. They also demonstrated a strong correlation between credit risk and operational risk. Furthermore, high-level economic, social, and governance (ESG) scores and corporate social responsibility (CSR) activities in general were 
regarded as signals of good corporate governance. CSR can decrease firms' cost of capital if the CSR activity is related to social (Waddock - Graves 1997) or environmental (Sharfman Fernando 2008) issues. Even reporting on CSR reduces financing costs (Dhaliwal et al. 2011). Kaufmann and Lafarre (2020) highlighted that firm-level and country-level governance are closely related; better country-level governance is associated with higher corporate social performance across EU countries.

Country-specific operational risk is of primary importance to foreign direct investors with controlling ownership in a business outside their home country. Foreign direct investors might face a business environment very different from their home environment; they have to cope with different business norms and cultures, different legal jurisdictions and regulations, and the threat posed by political instability. Industry practitioners ranked geopolitical risk as one of the top 10 most threatening risk category (Risk.net 2020). Geopolitical risk may take many forms such as regulatory burden, violence and civil unrest, human rights violations, and cultural missteps (Dehn - Everington 2020), with all these risk factors being strongly connected to the quality of country-level governance.

Moosa and $\mathrm{Li}$ (2013) argue that the cross-country variation in operational risk is related to cross-country differences in factors being connected to inadequate or failed internal processes, people, and systems, or external events. They reason that these factors (e.g., regulation, transparency and disclosure requirements, ethical standards, corruption, corporate governance, legal systems) are different across countries resulting in different patterns for the severity and frequency of operational losses. Cope et al. (2012) and Li and Moosa (2015) carefully motivate for five country-level determinants employed in this research as well: 1) size of the economy proxied by the GDP, 2) living standards measured by per capita GNI, 3) the quality of a country's governance, 4) the type of the legal jurisdictions, and 5) geographical regions.

In the empirical literature, a consensus seems to emerge. Most importantly, good governance is believed to have a negative effect on the severity and a positive effect on the frequency of operational loss events, see Table 1. In better governed countries, operational loss events are documented to be less severe but more frequent.

Cope et al. (2012) investigated the database of Operational Riskdata eXchange (ORX), a leading data consortium of 13 international banks sharing their own operational loss records containing many relatively small losses as well. They found that two governance indicators, the rule of law and the control of corruption have significant negative effect on the severity in the case of two event types, external frauds and clients and products and business practices, respectively. Li and Moosa (2015) included only country-level explanatory variables in their model and found that the average severity of operational loss events was negatively, while the frequency was positively related to country-level worldwide governance indicators as defined by the World Bank (World Bank, 2020a). Curti and Mihov (2018) documented that fraud recovery rates were higher in better governed countries even after controlling for several country-, bank-, or event-related variables. In this way, the authors provided a plausible explanation why there is a negative relationship between country-level governance and the size of operational losses. Similar to Cope et al. (2012), Alifano et al. (2019) also investigated the ORX database, but for a more recent period, and found that in the banking sector, four governance sub-indices had significant negative effects on the loss amounts.

Table 1 shows that the previous literature either relates to the pre-crisis period (Cope et al. 2012; Li - Moosa 2015); focuses only on the banking sector (Cope et al. 2012; Alifano et al. 2019); 
Table 1. Empirical evidence: the effects of country-level governance on operational risks

\begin{tabular}{|l|c|c|c|c|c|}
\hline Study & Cope et al. (2012) & Li and Moosa (2015) & Curti and Mihov (2018) & Alifano et al. (2019) & This study \\
\hline Dependent variable* & severity (-) & $\begin{array}{c}\text { severity (-) and } \\
\text { frequency (+) }\end{array}$ & severity (-) & $\begin{array}{c}\text { severity (-) } \\
\text { frequency (insignificant) } \\
\text { and severity } \\
\text { (insignificant) }\end{array}$ \\
\hline $\begin{array}{l}\text { Significant and robust } \\
\text { governance indicators }\end{array}$ & $\begin{array}{c}\text { Rule of Law, Control } \\
\text { of Corruption }\end{array}$ & $\begin{array}{c}\text { Aggregate Worldwide } \\
\text { Governance Indicator, } \\
\text { Regulatory Quality }\end{array}$ & $\begin{array}{c}\text { Aggregate Worldwide } \\
\text { Governance Indicator, } \\
\text { Control of Corruption, } \\
\text { Rule of Law, Regulatory } \\
\text { Quality, Government } \\
\text { Effectiveness }\end{array}$ & $\begin{array}{c}\text { Regulatory Quality, Rule } \\
\text { of Law, Control of } \\
\text { Corruption, Governance } \\
\text { Effectiveness }\end{array}$ & $\begin{array}{c}\text { None } \\
\text { Database }\end{array}$ \\
\hline ORX Global Loss \\
Database
\end{tabular}

*In brackets: the signs of the coefficients on governance indicators are shown.

Source: collected by the authors. 
or assesses only the severity of operational losses (Cope et al. 2012; Curti - Mihov 2018; Alifano et al. 2019). In this study, similarly to Li and Moosa (2015), we investigate how country-level governance indicators are associated with the severity and frequency of operational loss events across all industries. Nevertheless, in comparison with Li and Moosa (2015), we cover a more recent period (2008-2019 vs 1975-2008), a much larger sample of countries (132 countries vs 53 countries), and a higher number of loss events $(8,144 v s 4,388)$. Moreover, we split the sample into financial and non-financial industries given the differences in the regulation of operational risk management. Moreover, previous empirical literature focused mainly on loss severity; less attention has been devoted to loss frequency. In this research, in addition to severity (average loss amount), we investigate loss frequency, total loss amount, and the maximum loss amount as well. Finally, we explore some additional explanatory variables corresponding to megatrends that have not been analyzed in the literature of operational losses before.

\section{DATA AND METHODS}

Operational loss data are retrieved from the SAS OpRisk Global database, the world's most comprehensive and accurate repository of external loss events (SAS 2015; Wei et al. 2018). The database includes all publicly reported operational losses in excess of US $\$ 100,000$ across all industries worldwide. SAS OpRisk Global can be considered as the broadest possible statistical sample of large operational risk events (SAS 2015; Wei et al. 2018). Data are retrieved for the period of 2008-2019 covering 132 countries and 8,144 loss events.

In the basic regression model, the dependent variable is the severity, that is the average loss amount incurred in a given country over the sample period. For each country, severity is calculated as the ratio of the total loss amount to the total number of loss events in that country. In alternative model specifications, the frequency (the total number of loss events), the total loss amount, and the maximum loss amount are defined as dependent variables.

In the first series of runs, independent variables include country-level determinants potentially explaining the cross-country variation of operational risk as suggested by Li and Moosa (2015). Most importantly, the quality of a country's governance is measured by the Worldwide Governance Indicator which was retrieved from the database of the World Bank (World Bank 2020a). In the sample period, the six sub-indices are strongly correlated with each other (correlation coefficients ranging from 0.66 to 0.97 ) and with the aggregate governance indicator (correlation coefficients ranging from 0.84 to 0.98 ). Therefore, to avoid multicollinearity, we enter either the aggregate governance indicator or one of its sub-indices into the regressions.

In line with the literature, additional country-level determinants include proxies for the size of the economy (GDP), living standards (GNI per capita), the legal system, and the geographical region. GDP and GNI per capita data were retrieved from the database of the World Bank (World Bank 2020b; 2020c). Contemporary national legal systems were categorized as Englishtype (common law), French-type (French civic law), German-type (German civic law), or Scandinavian-type (Scandinavian civic law) (CIA 2020). Similar to Moosa and Li (2013) and Li and Moosa (2015), countries were allocated to one of eleven geographical regions (Africa, Australia and Oceania, Canada, China, Europe, Japan, Latin America, Middle East, South and East Asia, United Kingdom, United States). 
The ordinary least squares (OLS) regression model, similar to Li and Moosa (2015), is specified as shown in Eq. (1):

$$
\ln L O S S_{i}=\alpha+\beta \ln G D P_{i}+\varphi \ln G N I_{i}+\gamma G O V_{i}+\sum_{j} \delta_{i, j} L E S_{i j}+\sum_{k} \lambda_{i, k} R E G_{i k}+\varepsilon_{i}
$$

where $L O S S_{i}$ is the severity in country $i$; $G D P_{i}$ is the gross domestic product; $G N I_{i}$ is the gross national income per capita; $G O V_{i}$ is the governance indicator; and $L E S$ and $R E G$ are dummy variables for the legal systems and geographical regions, respectively. In alternative model specifications, $L_{O S S}$ is defined as the frequency of loss events, the total amount of losses, or the maximum loss amount in country i. GOV $i$ is either the aggregate Worldwide Governance Indicator or one of the six sub-indices; in all the cases, a higher value corresponds to better governance.

In the second series of runs, we extend the model specified by Li and Moosa (2015) by several additional variables which may explain the cross-country differences in the severity and frequency of operational loss events. We identify three important megatrends that may impact operational losses: (i) economic development and technological advancement, (ii) globalization, and (iii) sustainability. Economic development and technological advancement determine production and services, the size, the structure, and the efficiency of the economy. As a result of technological advancement and the spread of information technologies, new types of operational loss events emerged, for example, cybercrime. Globalization also severely impacts the risk and return profile of different countries, results in the interaction of different cultures, the spread of good practices and a certain level of convergence, for example, in the field of financial regulation. Finally, sustainability is also closely linked to operational risks; both environmental and social challenges are crucial in this regard (Anderson - Anderson 2009; Naffa - Fain 2021).

To reveal the effect of the above megatrends on operational losses, we introduce three new proxy variables to our model corresponding to each megatrend. First, the GDP growth rate, the market capitalization (percentage of GDP), and the number of mobile subscriptions (per 100 people) represent economic development and technological advancement. Previous literature suggests that the GDP growth serves as a proxy for the phase of the business cycle (expansion versus recession), and during economic downturn the frequency and severity of loss events are higher (Abdymomunov et al., 2020). It is reasonable to assume that in economically more developed countries more loss events occur whose average severity is higher. Note that GNI per capita has been excluded from this category due to its high correlation with several other variables (see Online Supplementary Material Table S2).

Second, we include three variables for globalization defined as the embeddedness of a country in the global economy: the export to GDP ratio, the high technology export to manufactured exports ratio, and the net foreign direct investment. The effect of globalization is ambiguous. On the one hand, globalization has led to increased production for businesses in order to meet global demand. Increased production, in turn, is associated with higher operational risk. On the other hand, globalization has accelerated the implementation of good management practices, including operational risk management as a result of which less severe operational loss events occur. Supposing that the income effect is captured by the GDP, we can reasonably assume that globalization decreases both severity and frequency given the widescale acceptance of the best know-hows. 
Third, we include three country-level sustainability measures in the analysis: $\mathrm{CO}_{2}$ emissions (metric tons per capita), the poverty headcount ratio (percentage of population below the national poverty line), and the income share held by the lowest $20 \%$. Most importantly, Zhao et al. (2016) reported for Chinese listed companies that companies improving their social responsibilities fulfillment face significantly lower operational risk. Thus, it might be reasonable to assume that the same observation holds at a country level, hence a lower ratio of $\mathrm{CO}_{2}$ emissions per GDP can be a sign of more responsible operations. Income inequality can be a serious source of tension, jeopardizing sustainability and increasing operational risk. Socially responsible firms are less risky (Waddock - Graves 1997). Similarly, countries with a higher level of social cohesion are expected to be less risky as well. The detailed description of the new variables included in the extended model is displayed in Online Supplementary Material Table S1.

The ordinary least squares (OLS) regression equation for the extended model is specified as shown in Eq. (2):

$$
\begin{aligned}
\ln \text { LOSS }_{i}= & \alpha+\beta \ln \text { GDP }_{i}+\gamma G O V_{i}+\sum_{j} \delta_{i, j} \text { LES }_{i j}+\sum_{k} \lambda_{i, k} \text { REG }_{i k}+\eta G D P \text { growth }_{i} \\
& +\theta \text { Market cap }_{i}+\iota \text { Mobile subscription }_{i}+\kappa \text { Export }_{i}+\theta \text { Hicht tech export }_{i} \\
& +\vartheta \ln \text { FDI net }_{i, t}+\mu \text { CO }_{2_{i}}+\tau \text { Poverty }_{i}+\omega \text { Income share }_{i}+\varepsilon_{i, t},
\end{aligned}
$$

where $\operatorname{LOSS}_{i}$ is the loss severity in country $i$; GDP $i$ is the gross domestic product; $G O V_{i}$ is the aggregate Worldwide Governance Indicator; $L E S$ and $R E G$ are dummy variables for the legal systems and the geographical regions, respectively; GDPgrowth $h_{i}$ is the change in the GDP; Market cap $p_{i}$ is the market capitalization; Mobile subscriptions $s_{i}$ is the number of subscriptions per 100 people; Export ${ }_{i}$ is the level of export in the percentage of the GDP; High tech export is $_{i}$ the high technology export in the percentage of manufactured export; FDI net ${ }_{i}$ is the net foreign direct investment; $\mathrm{CO}_{2}$ is the level of $\mathrm{CO}_{2}$ emissions in metric tons per capita; Poverty is the

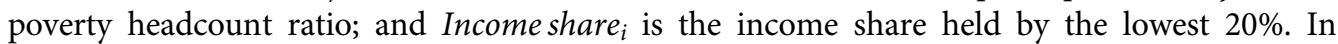
alternative model specifications, LOSS $_{i}$ is defined as the frequency of loss events, the total amount of losses, or the maximum loss amount in country $i$.

We take the natural logarithm of the following variables due to their large range and skewed distribution: frequency, severity, total loss, and GDP (in both series of runs); GNI per capita (when replicating the model of $\mathrm{Li}$ and Moosa); and net FDI (when extending the model of Li and Moosa (2015). Outliers are detected using box plots. Extreme outliers, as defined by Dawson (2011), are winsorized at the 1 percent and 99 percent levels as appropriate.

To test the robustness of the findings, we run a set of alternative model specifications for the dependent variables of average severity, frequency, and total loss. Robustness tests are performed for both series of runs: the replication of the Li and Moosa (2015) model and its extension. First, due to the high frequency and severity of losses in the financial sector, OLS regressions are run for the financial sector only, and for all industries excluding the financial sector. Second, we split the sample period into two sub-periods. The period of 2008-2013 covers the subprime crisis and the subsequent follow-up recession, while the period of 2014-2019 covers the post-crisis period. Third, we include only 53 countries in the sample. When replicating the model of Li and Moosa (2015), we include the same countries as the authors do. When extending the model of Li and Moosa (2015) with several explanatory variables, we include the 53 countries with the largest GDP. 


\section{RESULTS}

\subsection{Descriptive statistics}

The final sample includes 132 countries and 8,144 loss events with a total loss amount of almost 490 billion USD adjusted for inflation. The smallest loss amount in the sample is $\$ 0.1$ million, while the largest is 20,803 million. Online Supplementary material Table S2 shows some additional details about the dependent variables (frequency, severity, and total loss). Online Supplementary material Figure S1 presents the distribution of the average loss amounts for the 132 countries during the sample period.

Table 2 shows the distribution of operational losses by event type for all industries. The most frequent operational loss events are caused by business processes (clients, products, and business practices) and frauds (internal and external). The highest amount of total losses is attributable to business processes followed by damages to physical assets. The financial sector is responsible for $38 \%$ of the total losses followed by the mining industry (24\%), manufacturing (18\%), and utilities (11\%). The sample is dominated by loss events occurring in the US; more than half of the loss events $(50.77 \%)$ were recorded there.

Figure 1 presents the evolution of three key measures over time: severity and frequency of losses, and the aggregate Worldwide Governance Indicator (GOV). In the period of 2008-2019, there was a declining trend both in the number and the size of loss events, while the aggregate Worldwide Governance Indicator was stable over time.

Online Supplementary material Table S2 shows the descriptive statistics (mean, minimum, maximum, and standard deviation) for all the independent variables. The table includes the descriptive statistics for the variables in the model of Li and Moosa (2015) and in the extended model specified in this research as well. Online Supplementary material Table S3 shows the correlation among the variables. Please note that GNI per capita was excluded from the extended model specified in this research due to its high correlation $(\rho>0.6)$ with several other variables. The correlation coefficients among the variables included in the extended model are always lower than 0.6 in order to avoid multicollinearity.

\subsection{Regression results}

4.2.1. Replication of Li and Moosa (2015). First, we replicate the model of Li and Moosa (2015) by using the same explanatory variables as the authors. The regression results for the average loss amount are shown in Table 3. The aggregate governance indicator is included in these model specifications. We run separate regressions for the total sample, for the financial sector only, and for all industries except the financial sector. In additional robustness tests we split the sample period into two: the subprime crisis and the following recession vs the postcrisis period. The last two columns of the table, for comparison purposes, show the regression results for the 53 sample countries of Li and Moosa (2015).

As shown in Table 3, the aggregate governance indicator is not associated with the severity of losses in any of the model specifications; severe operational losses may incur regardless of the governance quality. At the same time, Table 3 reveals that the size of the economy, proxied by GDP, is a highly significant determinant of the average loss amount in each model: the larger the economy, the higher the average loss amount. In contrast, the living standards in a country, 
Table 2. Distribution of operational losses by event type, 2008-2019

\begin{tabular}{|l|c|c|c|c|c|c|}
\hline & \multicolumn{2}{|c|}{ All industries } & \multicolumn{2}{c|}{ Financial sector } & \multicolumn{2}{c|}{ Total excluding the financial sector } \\
\cline { 2 - 7 } & $\begin{array}{c}\text { Number of } \\
\text { losses (\%) }\end{array}$ & $\begin{array}{c}\text { Total amount of } \\
\text { losses (\$BN) (\%) }\end{array}$ & $\begin{array}{c}\text { Number of } \\
\text { losses (\%) }\end{array}$ & $\begin{array}{c}\text { Total amount of } \\
\text { losses (\$BN) (\%) }\end{array}$ & $\begin{array}{c}\text { Number of } \\
\text { losses (\%) }\end{array}$ & $\begin{array}{c}\text { Total amount of } \\
\text { losses (\$BN) (\%) }\end{array}$ \\
\hline $\begin{array}{c}\text { Business Disruption and } \\
\text { System Failures }\end{array}$ & $153(1.88 \%)$ & $11(2.16 \%)$ & $40(0.8 \%)$ & $2(1.33 \%)$ & $113(3.56 \%)$ & $8(2.65 \%)$ \\
\hline $\begin{array}{c}\text { Clients. Products and } \\
\text { Business Practices }\end{array}$ & $3,329(40.88 \%)$ & $191(38.93 \%)$ & $1,941(39.03 \%)$ & $96(52.3 \%)$ & $1,388(43.77 \%)$ & $94(30.88 \%)$ \\
\hline $\begin{array}{l}\text { Damage to Physical } \\
\text { Assets }\end{array}$ & $850(10.44 \%)$ & $166(33.95 \%)$ & $40(0.8 \%)$ & $3(1.51 \%)$ & $810(25.54 \%)$ & $164(53.47 \%)$ \\
\hline $\begin{array}{c}\text { Employment Practices } \\
\text { and Workplace Safety }\end{array}$ & $351(4.31 \%)$ & $13(2.67 \%)$ & $135(2.71 \%)$ & $2(1.35 \%)$ & $216(6.81 \%)$ & $11(3.46 \%)$ \\
\hline $\begin{array}{l}\text { Execution. Delivery and } \\
\text { Process Management }\end{array}$ & $714(8.77 \%)$ & $12(2.49 \%)$ & $501(10.07 \%)$ & $8(4.54 \%)$ & $213(6.72 \%)$ & $4(1.26 \%)$ \\
\hline External Fraud & $1,505(18.48 \%)$ & $45(9.28 \%)$ & $1,219(24.51 \%)$ & $27(14.9 \%)$ & $286(9.02 \%)$ & $18(5.9 \%)$ \\
\hline Internal Fraud & $1,242(15.25 \%)$ & $52(10.53 \%)$ & $1,097(22.06 \%)$ & $44(24.07 \%)$ & $145(4.57 \%)$ & $7(2.37 \%)$ \\
\hline Total & $8,144(100 \%)$ & $490(100 \%)$ & $4,973(100 \%)$ & $184(100 \%)$ & $3,171(100 \%)$ & $306(100 \%)$ \\
\hline
\end{tabular}

Source: SAS OpRisk Global. 


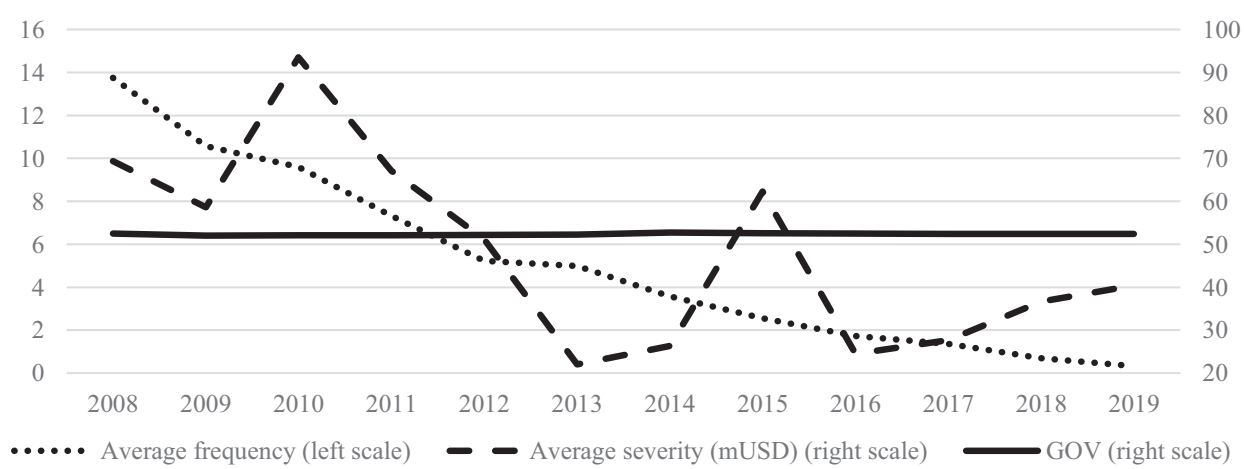

Fig. 1. Frequency and severity of losses, and quality of governance 2008-2019, average values. Source: SAS 0pRisk Global. Variables are averaged across the sample countries for each year. Frequency: average values of the frequency of loss events (left-hand scale). Severity: average values of the severity of loss events in million US dollar (right-hand scale). GOV variable: average values of the aggregate Worldwide Governance Indicator scaled between 0 and 100 so that larger values indicate better governance (right-hand scale).

proxied by GNI per capita, are not associated with the average loss amount in any of the specifications. Similarly, neither the legal system adopted in a country, nor the geographic region in which the country is located in are systematically associated with the severity across the specifications. (In Table 3, only the coefficient of the German legal system is significant for the subperiod of 2008-2013, while there are no significant coefficients for the geographic region.)

Using the aggregate indicator may conceal the fact that some dimensions of governance are more important than others. As a result, we run separate regressions for the six dimensions of a country's governance as measured by the World Bank (2020a). The estimation results for the average loss amount for the total sample are presented in Table 4. As shown in the table, no coefficients on the individual governance sub-indices are significant. When running the regressions for the 53 sample countries of Li and Moosa (2015), we find that although the coefficients on government effectiveness and control of corruption are significant, their positive sign contradicts the expected negative sign (see online Supplementary material Table S4).

For the total sample, Table 5 shows the regression results for three other dependent variables: the frequency of loss events, the total amount of losses, and the maximum loss amount. The size of the economy is a significant predictor in each specification, while the aggregate Worldwide Governance Indicator has no explanatory power. The frequency of loss events is negatively impacted by living standards and positively by adopting common law jurisdictions. As for the geographic region, there are significantly more loss events in the US than in any other region. We run five-five robustness tests for the dependent variables of frequency and total loss amount; see online Supplementary material Table S5 for the frequency of loss events, and Table S6 for the total amount of losses.

4.2.2. The extended model. In the second series of runs, we extend the model of Li and Moosa (2015) with several additional variables which may explain the cross-country differences in operational risk management. In the model specified for the whole sample (Table 6), two 
Table 3. Regression results for the severity (with the aggregate governance indicator) - Replication of Li and Moosa (2015)

\begin{tabular}{|c|c|c|c|c|c|c|c|c|c|c|c|c|c|}
\hline \multirow{3}{*}{\multicolumn{2}{|c|}{ Average severity }} & \multicolumn{10}{|c|}{132 countries } & \multirow{2}{*}{\multicolumn{2}{|c|}{$\begin{array}{l}53 \text { countries } \\
\text { All industries }\end{array}$}} \\
\hline & & \multicolumn{2}{|c|}{ All industries } & \multicolumn{2}{|c|}{ Financial sector } & \multicolumn{2}{|c|}{$\begin{array}{l}\text { Total excluding the } \\
\text { financial sector }\end{array}$} & \multicolumn{2}{|c|}{ Period 2008-2013 } & \multicolumn{2}{|c|}{ Period 2014-2019 } & & \\
\hline & & $\begin{array}{l}\text { Estimated } \\
\text { value }\end{array}$ & $P$-value & $\begin{array}{c}\text { Estimated } \\
\text { value }\end{array}$ & $P$-value & $\begin{array}{c}\text { Estimated } \\
\text { value }\end{array}$ & $P$-value & $\begin{array}{l}\text { Estimated } \\
\text { value }\end{array}$ & $P$-value & $\begin{array}{l}\text { Estimated } \\
\text { value }\end{array}$ & $P$-value & $\begin{array}{c}\text { Estimated } \\
\text { value }\end{array}$ & $P$-value \\
\hline \multicolumn{2}{|c|}{ InGDP } & 0.470 & $0.000^{* * *}$ & 0.353 & $0.000^{* * *}$ & 0.505 & $0.000^{* * *}$ & 0.534 & $0.000^{* * *}$ & 0.488 & $0.000^{* * *}$ & 0.666 & $0.000^{* * *}$ \\
\hline \multicolumn{2}{|c|}{ InGNI per capita } & -0.053 & 0.796 & -0.063 & 0.739 & -0.050 & 0.861 & -0.083 & 0.702 & -0.169 & 0.439 & -0.255 & 0.412 \\
\hline \multicolumn{2}{|c|}{ SUMGOV } & 0.018 & 0.693 & 0.068 & 0.107 & -0.022 & 0.726 & 0.005 & 0.916 & 0.089 & 0.070 & 0.123 & 0.060 \\
\hline \multirow[t]{4}{*}{ LES } & \multicolumn{13}{|c|}{ Reference: French system } \\
\hline & English system & 0.022 & 0.943 & 0.406 & 0.188 & -0.205 & 0.630 & -0.115 & 0.731 & 0.115 & 0.722 & -0.152 & 0.761 \\
\hline & German system & 0.473 & 0.191 & 0.144 & 0.669 & 0.505 & 0.280 & 0.824 & $0.039 *$ & -0.641 & 0.095 & 0.562 & 0.261 \\
\hline & Scandinavian system & 0.550 & 0.431 & -0.294 & 0.636 & -0.133 & 0.886 & 0.782 & 0.308 & -0.772 & 0.296 & -0.387 & 0.546 \\
\hline \multirow[t]{10}{*}{ REG } & \multicolumn{13}{|c|}{ Reference: US } \\
\hline & Africa & 0.577 & 0.690 & 0.172 & 0.893 & 0.097 & 0.957 & 0.495 & 0.755 & 0.851 & 0.580 & 2.656 & 0.070 \\
\hline & China & 0.776 & 0.683 & 2.485 & 0.138 & -0.376 & 0.870 & 0.410 & 0.844 & 2.437 & 0.226 & 1.290 & 0.429 \\
\hline & South and East Asia & 0.985 & 0.484 & 0.952 & 0.443 & 0.662 & 0.698 & 0.896 & 0.562 & 1.150 & 0.440 & 1.429 & 0.245 \\
\hline & Europe & 0.921 & 0.515 & 1.420 & 0.257 & 0.115 & 0.947 & 0.515 & 0.739 & 1.476 & 0.325 & 1.398 & 0.267 \\
\hline & Japan & 1.545 & 0.414 & 1.741 & 0.295 & 1.179 & 0.604 & 1.038 & 0.617 & 2.946 & 0.143 & 1.432 & 0.361 \\
\hline & Middle East & 0.776 & 0.587 & 0.787 & 0.535 & 0.283 & 0.872 & 0.280 & 0.858 & 0.772 & 0.611 & 2.065 & 0.137 \\
\hline & Australia and Oceania & 0.351 & 0.818 & 0.258 & 0.847 & 0.359 & 0.849 & 0.486 & 0.771 & 1.312 & 0.416 & 1.088 & 0.415 \\
\hline & Latin America & 1.057 & 0.459 & 0.755 & 0.553 & 0.395 & 0.821 & 0.952 & 0.543 & 0.702 & 0.642 & 1.902 & 0.168 \\
\hline & UK & 1.168 & 0.528 & 1.879 & 0.247 & -0.481 & 0.828 & 1.278 & 0.529 & 1.110 & 0.571 & 1.381 & 0.338 \\
\hline \multicolumn{2}{|c|}{ Constant } & -3.308 & 0.156 & -2.617 & 0.232 & -2.817 & 0.361 & -3.675 & 0.137 & -3.663 & 0.146 & -4.969 & 0.140 \\
\hline \multicolumn{2}{|l|}{$R^{2}$} & \multicolumn{2}{|l|}{0.405} & \multicolumn{2}{|l|}{0.511} & \multicolumn{2}{|l|}{0.314} & \multicolumn{2}{|l|}{0.406} & \multicolumn{2}{|l|}{0.429} & \multicolumn{2}{|l|}{0.507} \\
\hline
\end{tabular}

* $P<0.05$; ** $P<0.01$; *** $P<0.001$.

Note: SUMGOV is the aggregate Worldwide Governance Indicator, while LES is the legal system, and REG is the region. Source: authors. 
Table 4. Regression results for the severity (with the governance sub-indices), for 132 countries and all industries - Replication of Li and Moosa (2015)

\begin{tabular}{|c|c|c|c|c|c|c|c|c|c|c|c|c|c|}
\hline \multicolumn{2}{|c|}{ Average severity } & $\beta$ & $P$-value & $\beta$ & $P$-value & $\beta$ & $P$-value & $\beta$ & $P$-value & $\beta$ & $P$-value & $\beta$ & $P$-value \\
\hline \multicolumn{2}{|c|}{ InGDP } & 0.465 & $0.000^{* * *}$ & 0.481 & $0.000 * * *$ & 0.464 & $0.000 * * *$ & 0.463 & $0.000^{* * *}$ & 0.468 & $0.000^{* * *}$ & 0.469 & $0.000^{* * *}$ \\
\hline \multicolumn{2}{|c|}{ InGNI per capita } & -0.033 & 0.828 & -0.042 & 0.841 & -0.064 & 0.757 & 0.081 & 0.651 & -0.047 & 0.810 & -0.110 & 0.560 \\
\hline \multicolumn{2}{|l|}{ VOA } & 0.115 & 0.558 & & & & & & & & & & \\
\hline \multicolumn{2}{|l|}{ POS } & & & 0.074 & 0.756 & & & & & & & & \\
\hline \multicolumn{2}{|l|}{ GOE } & & & & & 0.123 & 0.649 & & & & & & \\
\hline \multicolumn{2}{|l|}{ REQ } & & & & & & & -0.140 & 0.517 & & & & \\
\hline \multicolumn{2}{|l|}{ ROL } & & & & & & & & & 0.091 & 0.701 & & \\
\hline \multicolumn{2}{|l|}{$\mathrm{COC}$} & & & & & & & & & & & 0.198 & 0.373 \\
\hline \multirow[t]{4}{*}{ LES } & \multicolumn{13}{|c|}{ Reference: French system } \\
\hline & English system & 0.031 & 0.919 & 0.035 & 0.907 & 0.011 & 0.970 & 0.062 & 0.839 & 0.021 & 0.945 & -0.006 & 0.986 \\
\hline & $\begin{array}{l}\text { German } \\
\text { system }\end{array}$ & 0.485 & 0.180 & 0.466 & 0.201 & 0.467 & 0.197 & 0.482 & 0.182 & 0.476 & 0.188 & 0.477 & 0.187 \\
\hline & $\begin{array}{l}\text { Scandinavian } \\
\text { system }\end{array}$ & 0.550 & 0.427 & 0.597 & 0.385 & 0.537 & 0.444 & 0.637 & 0.355 & 0.549 & 0.433 & 0.407 & 0.571 \\
\hline \multirow[t]{6}{*}{ REG } & \multicolumn{13}{|c|}{ Reference: US } \\
\hline & Africa & 0.603 & 0.677 & 0.578 & 0.690 & 0.555 & 0.701 & 0.570 & 0.694 & 0.582 & 0.688 & 0.529 & 0.714 \\
\hline & Canada & 0.351 & 0.850 & 0.384 & 0.836 & 0.352 & 0.850 & 0.448 & 0.809 & 0.375 & 0.840 & 0.268 & 0.885 \\
\hline & China & 0.935 & 0.628 & 0.713 & 0.707 & 0.715 & 0.706 & 0.666 & 0.725 & 0.777 & 0.683 & 0.780 & 0.680 \\
\hline & $\begin{array}{l}\text { South and } \\
\text { East Asia }\end{array}$ & 1.025 & 0.467 & 0.987 & 0.483 & 0.943 & 0.503 & 0.963 & 0.493 & 0.987 & 0.483 & 0.976 & 0.487 \\
\hline & Europe & 0.904 & 0.522 & 0.938 & 0.508 & 0.904 & 0.522 & 0.914 & 0.517 & 0.931 & 0.511 & 0.922 & 0.513 \\
\hline
\end{tabular}


Table 4. Continued

\begin{tabular}{|c|c|c|c|c|c|c|c|c|c|c|c|c|}
\hline Average severity & $\beta$ & $P$-value & $\beta$ & $P$-value & $\beta$ & $P$-value & $\beta$ & $P$-value & $\beta$ & $P$-value & $\beta$ & $P$-value \\
\hline Japan & 1.555 & 0.411 & 1.552 & 0.412 & 1.526 & 0.420 & 1.578 & 0.403 & 1.559 & 0.410 & 1.466 & 0.438 \\
\hline Middle East & 0.839 & 0.559 & 0.777 & 0.591 & 0.742 & 0.600 & 0.580 & 0.683 & 0.755 & 0.596 & 0.789 & 0.576 \\
\hline $\begin{array}{l}\text { Australia and } \\
\text { Oceania }\end{array}$ & 0.337 & 0.824 & 0.363 & 0.812 & 0.347 & 0.819 & 0.343 & 0.821 & 0.370 & 0.808 & 0.293 & 0.847 \\
\hline Latin America & 1.035 & 0.467 & 1.044 & 0.465 & 1.047 & 0.463 & 0.962 & 0.500 & 1.084 & 0.450 & 1.070 & 0.452 \\
\hline UK & 1.155 & 0.532 & 1.219 & 0.511 & 1.168 & 0.528 & 1.248 & 0.500 & 1.170 & 0.528 & 1.089 & 0.556 \\
\hline constant & -3.430 & 0.102 & -3.528 & 0.103 & -3.117 & 0.207 & -4.349 & $0.049 *$ & -3.333 & 0.150 & -2.755 & 0.232 \\
\hline$R^{2}$ & 0.406 & & 0.404 & & 0.405 & & 0.406 & & 0.405 & & 0.408 & \\
\hline
\end{tabular}

${ }^{*} P<0.05 ;{ }^{* *} P<0.01 ;{ }^{* * *} P<0.001$

Note: The components of the aggregate governance indicator are as follows 1$)$ voice and accountability (VOA); 2) political stability and absence of violence (POS); 3) government effectiveness (GOE); 4) regulatory quality (REQ); 5) rule of law (ROL); and 6) control of corruption (COC); while LES and REG stand for the legal system and the region.

Source: authors. 
Table 5. Regression results for frequency, total amount of losses, and maximum loss amount losses (with the aggregate governance indicator), 132 countries, all industries - Replication of Li and Moosa (2015)

\begin{tabular}{|c|c|c|c|c|c|c|c|}
\hline & \multicolumn{2}{|c|}{ Frequency } & \multicolumn{2}{|c|}{ Total amount of losses } & \multicolumn{2}{|c|}{ Maximum loss amount } \\
\hline & & $\begin{array}{l}\text { Estimated } \\
\text { value }\end{array}$ & $P$-value & $\begin{array}{c}\text { Estimated } \\
\text { value }\end{array}$ & $P$-value & $\begin{array}{l}\text { Estimated } \\
\text { value }\end{array}$ & $P$-value \\
\hline \multicolumn{2}{|c|}{ InGDP } & 0.390 & $0.000^{* * *}$ & 1.023 & $0.000^{* * *}$ & 1.141 & $0.000 * * *$ \\
\hline \multicolumn{2}{|c|}{ InGNIper capita } & -0.146 & $0.027^{*}$ & -0.230 & 0.249 & -0.271 & 0.288 \\
\hline \multicolumn{2}{|c|}{ SUMGOV } & 0.020 & 0.186 & 0.043 & 0.343 & 0.054 & 0.345 \\
\hline \multirow[t]{4}{*}{ LES } & \multicolumn{7}{|c|}{ Reference: French system } \\
\hline & English system & 0.348 & $0.001 * *$ & 0.572 & 0.058 & 0.597 & 0.120 \\
\hline & German system & -0.014 & 0.904 & 0.411 & 0.247 & 0.548 & 0.226 \\
\hline & $\begin{array}{l}\text { Scandinavian } \\
\text { system }\end{array}$ & -0.217 & 0.336 & 0.155 & 0.821 & 0.447 & 0.609 \\
\hline \multirow[t]{11}{*}{ REG } & \multicolumn{7}{|c|}{ Reference: US } \\
\hline & Africa & -2.974 & $0.000 * * *$ & -2.122 & 0.137 & -1.509 & 0.405 \\
\hline & Canada & -2.396 & $0.000 * * *$ & -1.761 & 0.335 & -1.360 & 0.559 \\
\hline & China & -2.690 & $0.000 * * *$ & -1.640 & 0.380 & -1.803 & 0.449 \\
\hline & $\begin{array}{c}\text { South and East } \\
\text { Asia }\end{array}$ & -2.798 & $0.000 * * *$ & -1.547 & 0.263 & -0.802 & 0.649 \\
\hline & Europe & -2.783 & $0.000 * * *$ & -1.500 & 0.280 & -0.753 & 0.670 \\
\hline & Japan & -2.764 & $0.000^{* * *}$ & -0.873 & 0.638 & -0.087 & 0.971 \\
\hline & Middle East & -3.507 & $0.000^{* * *}$ & -2.970 & $0.036^{*}$ & -2.242 & 0.212 \\
\hline & $\begin{array}{l}\text { Australia and } \\
\text { Oceania }\end{array}$ & -2.628 & $0.000 * * *$ & -1.778 & 0.234 & -1.615 & 0.396 \\
\hline & Latin America & -3.116 & $0.000 * * *$ & -2.060 & 0.143 & -1.273 & 0.476 \\
\hline & UK & -1.587 & $0.009 *$ & -0.151 & 0.934 & 0.371 & 0.873 \\
\hline \multicolumn{2}{|c|}{ constant } & 0.440 & 0.556 & -5.494 & $0.017^{*}$ & -5.608 & 0.055 \\
\hline \multicolumn{2}{|l|}{$R^{2}$} & \multicolumn{2}{|l|}{0.826} & \multicolumn{2}{|l|}{0.747} & \multicolumn{2}{|l|}{0.687} \\
\hline
\end{tabular}

${ }^{*} P<0.05 ; * * P<0.01 ;{ }^{* * *} P<0.001$.

Note: SUMGOV is the aggregate Worldwide Governance Indicator, while LES is the legal system, and REG is the region.

Source: authors. 
Table 6. Regression results for the severity (with the aggregate governance indicator) - Extended model

\begin{tabular}{|c|c|c|c|c|c|c|c|c|c|c|c|c|c|}
\hline & \multicolumn{10}{|c|}{132 countries } & \multirow{2}{*}{\multicolumn{2}{|c|}{$\begin{array}{l}53 \text { countries } \\
\text { All industries }\end{array}$}} \\
\hline & & \multicolumn{2}{|c|}{ All industries } & \multicolumn{2}{|c|}{ Financial sector } & \multicolumn{2}{|c|}{$\begin{array}{l}\text { Total excluding the } \\
\text { financial sector }\end{array}$} & \multicolumn{2}{|c|}{ Period 2008-2013 } & \multicolumn{2}{|c|}{ Period 2014-2019 } & & \\
\hline & & $\begin{array}{l}\text { Estimated } \\
\text { value }\end{array}$ & $P$-value & $\begin{array}{l}\text { Estimated } \\
\text { value }\end{array}$ & $P$-value & $\begin{array}{l}\text { Estimated } \\
\text { value }\end{array}$ & $P$-value & $\begin{array}{l}\text { Estimated } \\
\text { value }\end{array}$ & $P$-value & $\begin{array}{l}\text { Estimated } \\
\text { value }\end{array}$ & $P$-value & $\begin{array}{l}\text { Estimated } \\
\text { value }\end{array}$ & $P$-value \\
\hline Size of the economy & GDP & 0.520 & $0.000^{* * *}$ & 0.561 & $0.000^{* * *}$ & 0.546 & $0.000^{* * *}$ & 0.605 & $0.000^{* * *}$ & 0.387 & $0.001^{* *}$ & 0.634 & $0.016^{*}$ \\
\hline Country-level governance & SUMGOV & 0.025 & 0.543 & 0.025 & 0.534 & -0.015 & 0.796 & -0.007 & 0.871 & 0.025 & 0.577 & 0.012 & 0.863 \\
\hline \multirow[t]{4}{*}{ LES } & \multicolumn{9}{|c|}{ Reference: French system } & & & & \\
\hline & $\begin{array}{l}\text { English } \\
\text { system }\end{array}$ & 0.076 & 0.814 & 0.516 & 0.138 & -0.086 & 0.850 & 0.140 & 0.675 & -0.113 & 0.740 & -0.083 & 0.893 \\
\hline & $\begin{array}{l}\text { German } \\
\text { system }\end{array}$ & 0.539 & 0.148 & 0.744 & $0.043^{*}$ & 0.715 & 0.141 & 1.045 & $0.008^{* *}$ & -0.679 & 0.087 & 0.350 & 0.527 \\
\hline & $\begin{array}{c}\text { Scandinavian } \\
\text { system }\end{array}$ & 0.489 & 0.520 & 0.659 & 0.360 & -0.294 & 0.770 & 0.866 & 0.267 & -0.941 & 0.253 & 0.512 & 0.584 \\
\hline \multirow[t]{10}{*}{ REG } & \multicolumn{9}{|c|}{ Reference: US } & & & & \\
\hline & Canada & 0.389 & 0.839 & 0.515 & 0.770 & 0.034 & 0.988 & 1.052 & 0.649 & 1.342 & 0.615 & -0.059 & 0.974 \\
\hline & China & 1.250 & 0.582 & 1.185 & 0.572 & 1.782 & 0.517 & 2.629 & 0.498 & 3.313 & 0.152 & 3.226 & 0.192 \\
\hline & $\begin{array}{l}\text { South and } \\
\text { East Asia }\end{array}$ & 1.153 & 0.446 & 1.292 & 0.355 & 0.762 & 0.679 & 1.581 & 0.435 & 2.051 & 0.344 & 0.705 & 0.686 \\
\hline & Europe & 0.802 & 0.593 & 1.167 & 0.401 & -0.724 & 0.694 & 0.272 & 0.891 & 2.527 & 0.253 & -0.130 & 0.938 \\
\hline & Japan & 1.124 & 0.651 & 1.511 & 0.509 & -0.700 & 0.813 & 0.134 & 0.947 & 4.544 & 0.225 & -1.212 & 0.623 \\
\hline & Middle East & 0.704 & 0.638 & 0.880 & 0.527 & -0.026 & 0.989 & 1.114 & 0.580 & 1.187 & 0.585 & 0.959 & 0.583 \\
\hline & $\begin{array}{l}\text { Australia and } \\
\text { Oceania }\end{array}$ & 0.338 & 0.827 & 0.548 & 0.702 & -0.260 & 0.892 & 0.833 & 0.698 & 2.256 & 0.289 & 0.880 & 0.605 \\
\hline & Latin America & 1.095 & 0.457 & 1.420 & 0.301 & 0.110 & 0.951 & 1.442 & 0.477 & 1.620 & 0.444 & 0.813 & 0.658 \\
\hline & UK & 0.837 & 0.668 & 0.820 & 0.648 & -1.109 & 0.639 & 0.546 & 0.815 & 2.031 & 0.326 & 1.317 & 0.497 \\
\hline Economic development & GDP growth & -0.023 & 0.773 & -0.030 & 0.699 & -0.199 & 0.121 & -0.156 & $0.013^{*}$ & 0.010 & 0.888 & -0.161 & 0.298 \\
\hline advance & Market cap & -0.004 & 0.255 & -0.005 & 0.190 & -0.002 & 0.766 & -0.006 & 0.139 & 0.005 & 0.163 & -0.007 & 0.198 \\
\hline
\end{tabular}


Table 6. Continued

\begin{tabular}{|c|c|c|c|c|c|c|c|c|c|c|c|c|c|}
\hline & & \multicolumn{10}{|c|}{132 countries } & \multirow{2}{*}{\multicolumn{2}{|c|}{$\begin{array}{l}53 \text { countries } \\
\text { All industries }\end{array}$}} \\
\hline & & \multicolumn{2}{|c|}{ All industries } & \multicolumn{2}{|c|}{ Financial sector } & \multicolumn{2}{|c|}{$\begin{array}{l}\text { Total excluding the } \\
\text { financial sector }\end{array}$} & \multicolumn{2}{|c|}{ Period 2008-2013 } & \multicolumn{2}{|c|}{ Period 2014-2019 } & & \\
\hline & & $\begin{array}{l}\text { Estimated } \\
\text { value }\end{array}$ & $P$-value & $\begin{array}{l}\text { Estimated } \\
\text { value }\end{array}$ & $P$-value & $\begin{array}{l}\text { Estimated } \\
\text { value }\end{array}$ & $P$-value & $\begin{array}{l}\text { Estimated } \\
\text { value }\end{array}$ & $P$-value & $\begin{array}{l}\text { Estimated } \\
\text { value }\end{array}$ & $P$-value & $\begin{array}{l}\text { Estimated } \\
\text { value }\end{array}$ & $P$-value \\
\hline & $\begin{array}{c}\text { Mobile } \\
\text { subscriptions }\end{array}$ & 0.005 & 0.360 & 0.005 & 0.461 & 0.009 & 0.261 & 0.008 & 0.183 & 0.003 & 0.539 & 0.000 & 0.978 \\
\hline \multirow[t]{3}{*}{ Globalization } & Export & -0.001 & 0.913 & 0.002 & 0.814 & 0.000 & 0.982 & -0.001 & 0.848 & -0.004 & 0.626 & 0.013 & 0.226 \\
\hline & $\begin{array}{l}\text { High tech } \\
\text { export }\end{array}$ & 0.007 & 0.652 & 0.002 & 0.900 & -0.013 & 0.495 & 0.012 & 0.470 & 0.000 & 0.995 & -0.011 & 0.599 \\
\hline & FDI net & 0.000 & 0.982 & 0.000 & 0.966 & 0.000 & 0.740 & 0.000 & 0.756 & 0.000 & 0.642 & 0.000 & 0.200 \\
\hline \multirow[t]{3}{*}{ Sustainability } & $\mathrm{CO2}$ & 0.000 & 0.986 & -0.007 & 0.794 & -0.044 & 0.285 & -0.039 & 0.154 & 0.035 & 0.218 & -0.042 & 0.487 \\
\hline & Poverty & 0.026 & $0.044^{*}$ & 0.010 & 0.488 & 0.034 & 0.089 & 0.029 & $0.029 *$ & 0.014 & 0.344 & 0.026 & 0.356 \\
\hline & Income share & 0.131 & 0.216 & 0.057 & 0.617 & 0.209 & 0.147 & 0.164 & 0.132 & 0.069 & 0.522 & -0.083 & 0.681 \\
\hline \multicolumn{2}{|l|}{ Constant } & -6.287 & $0.009^{* *}$ & -6.265 & $0.007^{* *}$ & -5.585 & 0.097 & -7.460 & $0.007^{* *}$ & -6.257 & $0.026^{*}$ & -4.517 & 0.364 \\
\hline
\end{tabular}

* $P<0.05$; ** $P<0.01$; *** $P<0.001$.

Source: authors. 
Table 7. Regression results for frequency, total amount of losses, and maximum loss amount (with the aggregate governance indicator), all industries - Extended model

\begin{tabular}{|c|c|c|c|c|c|c|c|}
\hline & & \multicolumn{6}{|c|}{132 countries } \\
\hline & & \multicolumn{2}{|c|}{ Frequency } & \multicolumn{2}{|c|}{ Total amount of losses } & \multicolumn{2}{|c|}{ Maximum loss amount } \\
\hline & & $\begin{array}{l}\text { Estimated } \\
\text { value }\end{array}$ & $P$-value & $\begin{array}{l}\text { Estimated } \\
\text { value }\end{array}$ & $P$-value & $\begin{array}{l}\text { Estimated } \\
\text { value }\end{array}$ & $P$-value \\
\hline Size of the economy & GDP & 0.341 & $0.000 * * *$ & 1.006 & $0.000 * * *$ & 1.145 & $0.000 * * *$ \\
\hline Country-level governance & SUMGOV & 0.000 & 0.979 & 0.024 & 0.525 & 0.030 & 0.544 \\
\hline \multirow[t]{4}{*}{ LES } & \multicolumn{7}{|c|}{ Reference: French system } \\
\hline & English system & 0.387 & $0.000 * * *$ & 0.751 & $0.012 *$ & 0.779 & $0.049 *$ \\
\hline & German system & 0.054 & 0.622 & 0.628 & 0.068 & 0.773 & 0.088 \\
\hline & Scandinavian system & -0.373 & 0.101 & -0.088 & 0.900 & 0.269 & 0.770 \\
\hline \multirow[t]{10}{*}{ REG } & \multicolumn{7}{|c|}{ Reference: US } \\
\hline & Africa & -2.752 & $0.000 * * *$ & -1.825 & 0.187 & -1.253 & 0.491 \\
\hline & Canada & -2.008 & $0.001 * *$ & -1.142 & 0.518 & -0.649 & 0.781 \\
\hline & China & -3.181 & $0.000^{* * *}$ & -1.720 & 0.411 & -2.246 & 0.416 \\
\hline & South and East Asia & -2.551 & $0.000 * * *$ & -1.158 & 0.406 & -0.521 & 0.777 \\
\hline & Europe & -2.539 & $0.000 * * *$ & -1.449 & 0.295 & -0.774 & 0.671 \\
\hline & Japan & -1.704 & $0.023 *$ & -0.078 & 0.973 & 0.885 & 0.769 \\
\hline & Middle East & -3.350 & $0.000 * * *$ & -2.770 & 0.046 * & -2.176 & 0.232 \\
\hline & $\begin{array}{c}\text { Australia and } \\
\text { Oceania }\end{array}$ & -2.620 & 0.000 *** & -1.854 & 0.195 & -1.725 & 0.360 \\
\hline & Latin America & -3.027 & $0.000^{* * *}$ & -2.059 & 0.130 & -1.341 & 0.454 \\
\hline
\end{tabular}


Table 7. Continued

\begin{tabular}{|c|c|c|c|c|c|c|c|}
\hline & & \multicolumn{6}{|c|}{132 countries } \\
\hline & & \multicolumn{2}{|c|}{ Frequency } & \multicolumn{2}{|c|}{ Total amount of losses } & \multicolumn{2}{|c|}{ Maximum loss amount } \\
\hline & & $\begin{array}{l}\text { Estimated } \\
\text { value }\end{array}$ & $P$-value & $\begin{array}{l}\text { Estimated } \\
\text { value }\end{array}$ & $P$-value & $\begin{array}{c}\text { Estimated } \\
\text { value }\end{array}$ & $P$-value \\
\hline & UK & -1.953 & $0.001^{* *}$ & -1.203 & 0.503 & -0.807 & 0.734 \\
\hline \multirow{3}{*}{$\begin{array}{l}\text { Economic development and } \\
\text { technological advance }\end{array}$} & GDP growth & -0.016 & 0.504 & -0.087 & 0.232 & -0.054 & 0.573 \\
\hline & Market cap & 0.001 & 0.259 & -0.002 & 0.515 & -0.004 & 0.420 \\
\hline & Mobile subscriptions & 0.004 & $0.019 *$ & 0.013 & $0.015 *$ & 0.015 & $0.039 *$ \\
\hline \multirow[t]{3}{*}{ Globalization } & Export & -0.005 & $0.008^{* *}$ & -0.009 & 0.153 & -0.008 & 0.339 \\
\hline & High tech export & 0.006 & 0.184 & 0.016 & 0.250 & 0.016 & 0.389 \\
\hline & FDI net & 0.000 & $0.001^{* *}$ & 0.000 & 0.236 & 0.000 & 0.311 \\
\hline \multirow[t]{3}{*}{ Sustainability } & $\mathrm{CO2}$ & -0.012 & 0.127 & -0.039 & 0.102 & -0.040 & 0.210 \\
\hline & Poverty & 0.014 & $0.000 * * *$ & 0.044 & $0.000 * * *$ & 0.047 & $0.003^{* *}$ \\
\hline & Income share & 0.054 & 0.087 & 0.194 & $0.047^{*}$ & 0.210 & 0.103 \\
\hline \multicolumn{2}{|l|}{ constant } & -1.445 & $0.043^{*}$ & -10.637 & $0.000^{* * *}$ & -11.732 & $0.000^{* *}$ \\
\hline \multicolumn{2}{|l|}{$R^{2}$} & \multicolumn{2}{|l|}{0.860} & \multicolumn{2}{|l|}{0.789} & \multicolumn{2}{|l|}{0.720} \\
\hline
\end{tabular}

${ }^{*} P<0.05 ;{ }^{* *} P<0.01 ;{ }^{* * *} P<0.001$.

Source: authors. 
variables are significantly and positively associated with the severity of loss events: GDP and the poverty headcount ratio. Thus, the higher the country's GDP and the higher the proportion of the poor, the more severe operational loss events occur. The former finding is robust across various subsamples (financial vs non-financial sector; subprime crisis and the subsequent followup recession vs the post-crisis period; 53 countries with the largest GDP). The latter finding can be observed in one additional specification only: in the model covering the period of the subprime crisis and the subsequent recession.

For the total sample, Table 7 shows the regression results for the three other dependent variables. The size of the economy is again a significant predictor in each specification, while the aggregate Worldwide Governance Indicator is insignificant. In addition, the frequency of loss events is positively impacted by the number of mobile subscriptions and the proportion of inhabitants without minimum level of income deemed adequate in the particular country and negatively by the level of export (as a percentage of GDP). Although the coefficient of net FDI is also significant, it is economically irrelevant (with the coefficient being very close to zero). The findings are robust for GDP, the poverty headcount ratio, and the level of export sacross various alternative model specifications, see Online Supplementary Material Table S7. The total loss amount is positively impacted by the number of mobile subscriptions, the poverty headcount ratio, and the income held by the lowest $20 \%$. The findings are robust for GDP, the number of mobile subscriptions, and the poverty headcount ratio, see Online Supplementary Material Table S8. The maximum loss amount is impacted by the variables deemed robust for the total loss amount.

\section{DISCUSSION}

We find that the size of the economy is the only consistent predictor of the severity of operational loss; a finding being in line with Cope et al. (2012) and Li and Moosa (2015). This finding holds both for the replication (Table 3 ) and for the extended model (Table 6). In a larger economy, the value of transactions is higher which in turn leads to higher operational losses.

When replicating the model of Li and Moosa (2015), we find that the living standards in a country are not associated with the average loss amount. This finding contradicts the results of $\mathrm{Li}$ and Moosa (2015) who reported that the average severity is positively associated with the standard of living. It may well be the case that the variable lost its significance due to the general increase in the standard of living over the past decades.

At a country level, it is easier to model loss frequency than average severity; the R-squared is much higher for frequency than for severity ( 0.826 versus 0.405 in the replication, 0.860 versus 0.436 in the extended model). In the replication, we find that GDP, GNI per capita (a proxy for the living standards), the legal system, and geographic regions are significant explanatory factors for frequency. In larger economies, frequency tends to be higher: a 1\% larger GDP is coupled with $0.39 \%$ more losses on average, which can be explained by the larger number of firms operating in larger economies. Frequency is significantly higher in English-type legal systems, especially in the US, which is consistent with previous empirical findings in the literature (Table 1). At the same time, in our sample, GNI per capita is negatively associated with loss frequency. One percent larger living standards are associated with $0.15 \%$ less losses, which is contrary to Li and Moosa (2015). 
For loss severity, in the extended model, it is only GDP which proved to be both significant (with a positive sign) and robust in different specifications (Table 6). The German legal system is associated with higher losses in only two specifications (all industries, 132 countries: full period and the post-crisis period). The GDP growth rate and the poverty headcount ratio are also significant for severity (with negative and positive signs, respectively) but only in the post-crisis period.

For loss frequency, in the extended model, we find that GDP, the number of mobile subscriptions, the level of exports, and the poverty headcount ratio are significant explanatory variables - a finding robust across various specifications. Regarding GDP, the bank-level findings of Homolya (2011) match the country-level finding of this study: the larger the size, the higher the frequency of losses. Moreover, the higher the poverty headcount ratio at the national poverty lines, the higher the number of operational loss events. It may well be the case, that in poor countries there are less resources for security investments, including those affecting the human life, the environment, and the business operation. This finding is also in line with Li and Moosa (2015), who documented that the smaller the GNI (and thus poverty higher), the higher the frequency of loss events. For the level of exports (as a percentage of GDP), we document that the higher the level of exports, the lower the number of loss events. In general, higher level of export indicates higher level of globalization. Globalization accelerates economic growth and modernization, results in higher industrial productivity and trade between nations, and promotes the integration of financial markets. The modernization in production and the presumed modernization of the management systems, including risk management procedures, in turn, is associated with a lower number of operational loss events.

Our findings reveal, however, that during the period of 2008-2019 the aggregate governance indicator is associated neither with the severity nor with the frequency of operational loss events. This finding holds when replicating the model of Li and Moosa (2015) and when running its extended version, both for the sample of 132 countries and for the sample of 53 countries. The finding also holds when we split the sample into financial and non-financial sectors. When investigating the six dimensions of governance individually during the replication, for the sample of 132 countries, we find that none of the dimensions is a significant determinant of average severity. For the 53 sample countries, we find that two of the six dimensions (government effectiveness and control of corruption) are significant predictors of severity, however, the signs of the coefficients are positive. Hence, these findings contradict the hypothesis that in countries with high-quality governance, low-severity and high-frequency events are significantly more concentrated. Note that our findings also contradict the consensus in the literature detailed in Table 1, as we found no evidence for the severity of operational losses to be negatively related to governance indicators.

Explanations may be suggested as to why the quality of governance is not a significant determinant of operational losses anymore. First, there are differences in constructing the operational loss databases: the Fitch First qualitative database used by Li and Moosa (2015) and SAS Global used in this research. Fitch First, re-named to Algo First in 2005, has a loss reporting threshold of US \$1 million and focuses primarily on the US financial services industry (Wei et al. 2018). In contrast, SAS Global has a loss reporting threshold of US $\$ 100,000$, making the SAS Global a more comprehensive and accurate database (Wei et al. 2018). Second, a larger sample is used in this research. The dataset in Li and Moosa (2015) retrieved from Fitch First included 4,388 loss events with a total loss amount of 849 billion USD. When filtering for the 53 sample 
countries of Li and Moosa (2015), the SAS Global dataset used in this research includes 7,553 loss events with a total loss amount of 461 billion USD, for a sample period being 3.1 times shorter. In the sample of 132 countries, there are 8,144 loss events with a total loss amount of almost 490 billion USD. Third, this research covers a more recent period, years 2008-2019 in contrast to the sample period of 1975-2008 used by Li and Moosa (2015). Last but not least, in the past few decades, several dimensions of our life have changed significantly, which might have altered the interrelations between the model variables. The most important changes include the megatrends of economic development and technological advances, globalization, and sustainability.

Due to economic development and technological changes, the relative weights of event types have shifted remarkably, see Table S9 in the online Supplementary Material. Most importantly, the losses in the category of internal fraud and clients, products \& business practices became less severe; while external fraud events, including cybersecurity attacks, have become more frequent and severe in the past decade. IT disruption, data compromise, theft, and fraud are ranked as the top operational risks for 2020 by industry practitioners (Risk.net 2020). Cyber-attacks typically cross borders, hence, this risk is more independent of the quality of a country's governance. Moreover, operational risk is a heterogeneous category covering several types of risks, and the diversity of risk events has increased with recent technological advances. The quality of a country's governance may be associated with the severity and frequency of only particular event types but not all. In the extended model, the number of mobile subscriptions, a variable reflecting how widespread technological advances are in an economy, positively affects three out of four dependent variables (frequency, total loss, maximum loss) (Table 7). It may well be the case that nowadays technological development, the usage of technological advances, and the related complexity of the business processes has a more significant influence on operational loss events than the quality of country-level governance.

With recent globalization, several companies are owned by foreign investors. Companies with foreign ownership might follow different corporate governance and thus operational risk management practices than the ones accepted by local enterprises. As a result of increasing foreign ownership and flow of labor (managers and employees) across the globe, companies in a country might be less embedded and influenced by country-level governance characteristics. Although we included three measures of globalization in the extended model (exports, high technology exports and net FDI), these measures do not capture fully how widespread foreign ownership in an economy is. Nevertheless, we found that the higher the exports, the lower the number of loss events. In general, a high export level serves as an indication of a competitive economy and efficient business processes, including better risk management practices. As a result of better risk management practices, fewer operational loss events may occur.

As a result of globalization, regulatory harmonization (e.g., the introduction of Basel II and III), the legal framework of operational risk management is not only improving but also converging to each other. Thus, nowadays, institutional factors such as the application of advanced or less advanced models matter the most, and country-level governance factors are less relevant in determining the efficiency of risk management processes. Curti and Mihov (2018) found that fraud recovery (hence the size of losses) depends on the quality of a country's governance especially in the case of firms with poor risk management quality. Thus, as risk management practices improve, country-level governance is expected to become less important. Moreover, improved risk management practices spread to other industries as well. 
The importance of organizations that work toward a more sustainable future vary greatly across countries. Similarly, the attitude of the governments and their actions towards a more sustainable future are also different. Nevertheless, sustainability gained more attention all over the world, putting firms under pressure to improve their performance in environmental, social, and governance (ESG) dimensions. In this research, we documented the importance of sustainability for operational risk as well. In particular, we found that the poverty headcount ratio at the national poverty lines is positively associated with operational risk. This finding highlights the importance of reducing inequality and socioeconomic disparities and fractures in the society in order to reduce the frequency and in partly the severity of operational losses.

\section{CONCLUSIONS}

When replicating the model of Li and Moosa (2015), we find that the quality of a country's governance, the standard of living, the legal system, and the geographic region in which the country is located do not play any role in determining the severity of operational losses. Only GDP is associated consistently and positively with the severity and the frequency of losses.

The most striking result of this study is that the quality of governance in a country (the country-level equivalent of corporate governance) is not associated with the loss size in any of the model specifications (financial or non-financial companies; smaller or larger group of countries; subcomponents of the government indices, different time periods). This finding contradicts both the theoretical expectations and the empirical evidence documented in the literature. Due to economic development and technological advance, globalization, and sustainability, some country-specific factors might have lost their explanatory power. In line with these tendencies, it is possible that finding significant country-specific determinants of operational risk is becoming more and more difficult, and risk managers should concentrate on exploring firm-specific characteristics when modelling operational risk.

Risk managers, regulators, and other stakeholders prefer the "high frequency and low severity" (HFLS) regime to the "low frequency and high severity" (LFHS) regime not only at firm but also at country level. The LFHS regime seriously jeopardizes profitability and sustainability. The relevant empirical literature concluded that the quality of the governance is of major importance. Therefore, it is reasonable to believe that switching from the LFHS to HFLS regime requires improvement in the quality of governance. Although this belief may be true at a firm level, our findings reveal that the causality is more complex at country level.

Our findings indicate that geographical regions, hence historical and cultural differences are still very influential. Thus, to improve risk management practices, investors and policy makers need to identify regional specialties and promote cultural changes if deemed necessary, see for example the case study of Korean Air (Gladwell 2008). At the same time, it is also fundamental how a country copes with the megatrends. From an operational risk point of view, special attention needs to be devoted to factors like the export capacity of companies, the spread of technology, and poverty issues. In addition to country-level factors, analysts need to focus more and more on the operational characteristics of individual companies, for example, the firm's environmental, social, and governance scores relative to its peers. 


\section{ACKNOWLEDGMENTS}

This research was supported by the Higher Education Institutional Excellence Program 2020 of the Ministry of Innovation and Technology in the framework of the 'Financial and Public Services' research project (TKP2020-IKA-02) at Corvinus University of Budapest. Edina Berlinger's research was supported by the Bolyai János scholarship of the Hungarian Academy of Sciences. Zsuzsanna Tamásné Vőneki thanks SAS Global for the access to the database.

\section{SUPPLEMENTARY MATERIAL}

Supplementary data to this article can be found online at (https://doi.org/10.1556/204.2021. 00018).

\section{REFERENCES}

Abdymomunov, A. - Curti, F. - Mihov, A. (2020): US Banking Sector Operational Losses and the Macroeconomic Environment. Journal of Money, Credit and Banking 52(1): 115-144.

Alifano, D. - Corradi, V. - Distaso, W. (2019): The Determinants of Operational Risk Losses. Available at SSRN 3407863.

Allen, L. - Saunders, A. (2004): Incorporating Systemic Influences Into Risk Measurements: A Survey of the Literature. Journal of Financial Services Research 26(2): 161-191.

Anderson, D. R. - Anderson, K. E. (2009): Sustainability Risk Management. Risk Management and Insurance Review 46(6): 25.

BCBS (2004): International Convergence of Capital Measurement and Capital Standards: A Revised Framework. Basel Committee on Banking Supervision, June 2004. http://www.bis.org/publ/bcbs107. htm, accessed 03/10/2015.

Chernobai, A. - Jorion, P. - Yu, F. (2011): The Determinants of Operational Risk in U.S. Financial Institutions. Journal of Financial and Quantitative Analysis 46(6): 1683-1725.

CIA (2020): The World Factbook. Legal System. https://www.cia.gov/library/publications/the-worldfactbook/fields/308.html, accessed 05/01/2020.

Cope, E. W. - Piche, M. T. - Walter, J. S. (2012): Macroenvironmental Determinants of Operational Loss Severity. Journal of Banking \& Finance 36(5): 1362-1380.

Curti, F. - Mihov, A. (2018): Fraud Recovery and the Quality of Country Governance. Journal of Banking \& Finance 87: 446-461.

Dawson, R. (2011): How Significant is a Boxplot Outlier? Journal of Statistics Education 19(2).

Dhaliwal, D. S. - Li, O. Z. - Tsang, A. - Yang, Y. G. (2011): Voluntary Nonfinancial Disclosure and the Cost of Equity Capital: The Initiation of Corporate Social Responsibility Reporting. The Accounting Review 86(1): 59-100.

Dehn, C. - Everington, N. (2020): Geopolitical Risk - What is it and How Can Companies Respond to It? https://www.kroll.com/en/insights/publications/compliance-risk/companies-respond-geopolitical-risk, accessed 27/06/2020. 
ECB (2017): Supervisory Banking Statistics. https://www.bankingsupervision.europa.eu/ecb/pub/pdf/ssm. supervisorybankingstatistics_fourth_quarter_2017_201804.en.pdf, accessed 16/06/2018.

Gladwell, M. (2008): Outliers: The Story of Success. New York: Little, Brown and Company.

Homolya, D. (2011): Operational Risk and Its Relationship with Institution Size in the Hungarian Banking Sector. MNB Bulletin 6(2): 7-17.

Kaufmann, D. - Kraay, A. - Mastruzzi, M. (2011): The Worldwide Governance Indicators: Methodology and Analytical Issues. Hague Journal on the Rule of Law 3(2): 220-246.

Kaufmann, W. - Lafarre, A. (2020): Does Good Governance Mean Better Corporate Social Performance? A Comparative Study of OECD Countries. International Public Management Journal 1-30.

Li, L. - Moosa, I. (2015): Operational Risk, the Legal System and Governance Indicators: A Country-Level Analysis. Applied Economics 47(20): 2053-2072.

Moosa, I. A. - Li, L. (2013): The Frequency and Severity of Operational Losses: A Cross-Country Comparison. Applied Economics Letters 20(2): 167-172.

Naffa, H. - Fain, M. (2020): Performance Measurement of ESG-Themed Megatrend Investments in Global Equity Markets Using Pure Factor Portfolios Methodology. Plos One 15(12): e0244225.

Naffa, H. - Fain, M. (2021): A factor Approach to the Performance of ESG Leaders and Laggards. Finance Research Letters 102073.

Risk.net (2020): Top 10 Operational Risks for 2020. The Biggest op Risks for 2020, as Chosen by Industry Practitioners. https://www.risk.net/risk-management/7450731/top-10-operational-risks-for-2020, accessed 27/06/2020.

SAS (2015): SAS ${ }^{\circledR}$ OpRisk Global Data. https://www.sas.com/content/dam/SAS/en_us/doc/productbrief/ sas-oprisk-global-data-101187.pdf, accessed 16/01/2020.

Sharfman, M. P. - Fernando, C. S. (2008): Environmental Risk Management and the Cost of Capital. Strategic Management Journal 29(6): 569-592.

Waddock, S. A. - Graves, S. B. (1997): The Corporate Social Performance-Financial Performance Link. Strategic Management Journal 18(4): 303-319.

Wei, L. - Li, J. - Zhu, X. (2018): Operational Loss Data Collection: A Literature Review. Annals of Data Science 5(3): 313-337.

World Bank (2020a): World Governance Indicators. The World Bank DataBank. https://databank. worldbank.org/source/worldwide-governance-indicators, accessed 10/01/2020.

World Bank (2020b): GDP. The World Bank DataBank. https://databank.worldbank.org/source/worlddevelopment-indicators, accessed 10/01/2020.

World Bank (2020c): GNI Per Capita. The World Bank DataBank. https://databank.worldbank.org/source/ world-development-indicators, accessed 10/01/2020.

Zhao, C. - Song, H. - Chen, W. (2016): Can Social Responsibility Reduce Operational Risk: Empirical Analysis of Chinese Listed Companies. Technological Forecasting and Social Change 112: 145-154.

Open Access. This is an open-access article distributed under the terms of the Creative Commons Attribution 4.0 International License (https://creativecommons.org/licenses/by/4.0/), which permits unrestricted use, distribution, and reproduction in any medium, provided the original author and source are credited, a link to the CC License is provided, and changes - if any - are indicated. (SID_1) 